\title{
Findings About Events or Interventions Group Identifier
}

National Cancer Institute

\section{Source}

National Cancer Institute. Findings About Events or Interventions Group Identifier. NCI

Thesaurus. Code C87887.

A character or string that represents a findings group. 